\title{
Rotifera from Burundi : the Lecanidae (Rotifera : Monogononta)
}

\author{
D.Baribwegure ${ }^{1,2}$ \\ H. Segers ${ }^{1}$
}

Keywords : Rotifera, Lecanidae, zoogeography, biodiversity, distribution, Burundi.

\begin{abstract}
As part of a survey of the rotifer fauna of Burundi, Lecanidae from Kashiru and the floodplain of the river Rusizi in Northwest Burundi are reported. Thirty-four species of Lecane were found. Twenty-five of them are new to Burundi, raising the total Burundian Lecane record to thirty-five. Three species, Lecane aeganea Harring, 1914, L. eswari Dhanapathi, 1976 and $L$. subulata (Harring \& Myers, 1926) are new to the African fauna, the presence of $L$. baimaii Sanoamuang \& Savatenalinton, 1999 in Africa is confirmed. The fauna consists mainly of cosmopolitan and tropicopolitan taxa, accompanied by several Eastern Hemisphere taxa, and one each of pantropical, endemic and arctic-temperate taxa. The latter, occurring in a high-altitude locality, may be a glacial relict.
\end{abstract}

\section{Rotifères du Burundi : les Lecanidae (Rotifera : Monogononta)}

Mots clés : Rotifères, Lecanidae, zoogéographie, biodiversité, distribution, Burundi.

Les Lecanidae de Kashiru et de la plaine de la Rusizi, au Nord-Ouest du Burundi, sont présentés. 34 espèces du genre Lecane ont été identifiées. Parmi elles, 25 sont nouvelles pour la faune rotatorienne Burundaise, ce qui porte à 35 la liste des Lecane burundais. La présence en Afrique de Lecane baimaii Sanoamuang \& Savatenalinton, 1999 est confirmée et Lecane aeganea Harring, 1914, Lecane eswäri Dhanapathi, 1976 ainsi que Lecane subulata (Harring \& Myers, 1926) sont nouvelles pour la faune africaine. Cette étude montre la prédominance des taxons cosmopolites et thermophiles, accompagnés d'espèces de l'hémisphère Est. Une espèce pantropicale et une endémique africaine ont également été trouvées. Une espèce connue de la région tempérée arctique apparaît en haute altitude et constitue probablement une relique glaciaire.

\section{Introduction}

The genus Lecane Nitzsch, 1827 generally constitutes the most diverse group of rotifers in many types of tropical freshwater body (Dussart et al. 1984, Segers et al. 1993). Over the years, some information has accumulated on the distribution of Rotifera in Africa (see De Ridder, 1986, 1991, 1994). However, little is known on the distribution of rotifers in Burundi, and of members of this genus in particular. Gillard (1957) lis-

1. Laboratory of Animal Ecology, Zoogeography and Nature Conservation, Department Biology, Ghent University, K.L. Ledeganckstraat, 35, B-9000 Gent, Belgium.

2. Département de Biologie, Faculté des Sciences, Université du Burundi, B.P. 2700 Bujumbura, Burundi. ted 11 Lecanidae from localities in and around Lake Tanganyika, but only nine of these were recorded from the Burundian part of the lake, a swamp near river Rusizi. The remaining material originates from other countries bordering the lake, or no precise locality is provided. Coulter in De Ridder (1991) lists 14 Lecanidae from Lake Tanganyika, including Gillard's (1957) L. vandenbrandei. However, this taxon is considered an unrecognisable species inquirenda by Segers (1995a). Recently, Segers \& Baribwegure (1996) described a regional endemic, Lecane tanganyikae Segers \& Baribwegure from the Rusizi floodplain near Lake Tanganyika. So, a total of only ten Lecane species had so far been recorded from the country, while five more were reported from Lake Tanganyika. This number is low, compared to reports like Segers et al. (1993), in which 59 Lecane are reported in a single survey. 
In order to contribute to the knowledge on the rotifer fauna of Burundi and on the distribution of Lecanidae in Africa, we investigated 34 samples from ten water bodies in the floodplain of the river Rusizi and from the high-altitude region of Kashiru near Ijenda. This work reports on the results of these investigations, and complements the results for Lepadellidae (Baribwegure \& Segers, in press).

\section{Material and methods}

For this study, the Lecanidae of samples from 10 localities were studied. Most were collected by one of us (DB), using $35 \mu \mathrm{m}$-mesh plankton net and preserved in $4 \%$ formalin. Other material consists of samples collected in Burundi on different occasions as indicated below. Specimens were picked under a WILD M3 dissection microscope, examined and drawn under a Medilux-12 microscope with drawing tube at $1000 \mathrm{x}$ magnification. Identification was done using Segers (1995a).

All but one locality are in the floodplain of river Rusizi (Map 1). This floodplain extends some $80 \mathrm{~km}$ along the river in the west and Northwest Burundi. It is situated from the northern bay of Lake Tanganyika up to the confluence of river Rusizi with river Ruhwa at the border between Burundi and Rwanda. The area is located between $2^{\circ} 45^{\prime}-3^{\circ} 30^{\prime} \mathrm{S}$ and $29^{\circ} 10^{\prime}-29^{\circ} 15^{\prime} \mathrm{E}$ at an altitude varying between 740 and $900 \mathrm{~m}$. The climate is tropical with two rainy seasons (February May and November - December).

The following localities were sampled in the floodplain of River Rusizi :

- Locality 1 : Littoral zone of Lake Tanganyika between "Musée Vivant" and the port of Bujumbura (two samples, leg. H.J. Dumont, 01 May 1983)

- Localities 2 and 3 : Two natural lakes in the delta of River Rusizi near Lake Tanganyika (Park of Rusizi) (Five and six samples, respectively, 5 - 11 July 1996).

- Locality 4 : Small water bodies and connecting ditch between localities 2 and 3, Park of Rusizi (Six samples, 3 - 9 July 1996).

- Locality 5 : Temporary pond in Rukoko (Reserve of Rusizi), North of Bujumbura airport (Three samples, leg. A. Caljon, 21 December 1981).

- Locality 6 : Pond near River Kajeke (One sample, leg. A. Caljon, 09 April 1990).

- Localities 7 and 8 : Two rice fields along a road to Rukaramu project near Bujumbura airport (Two samples each, 26 March 1996).

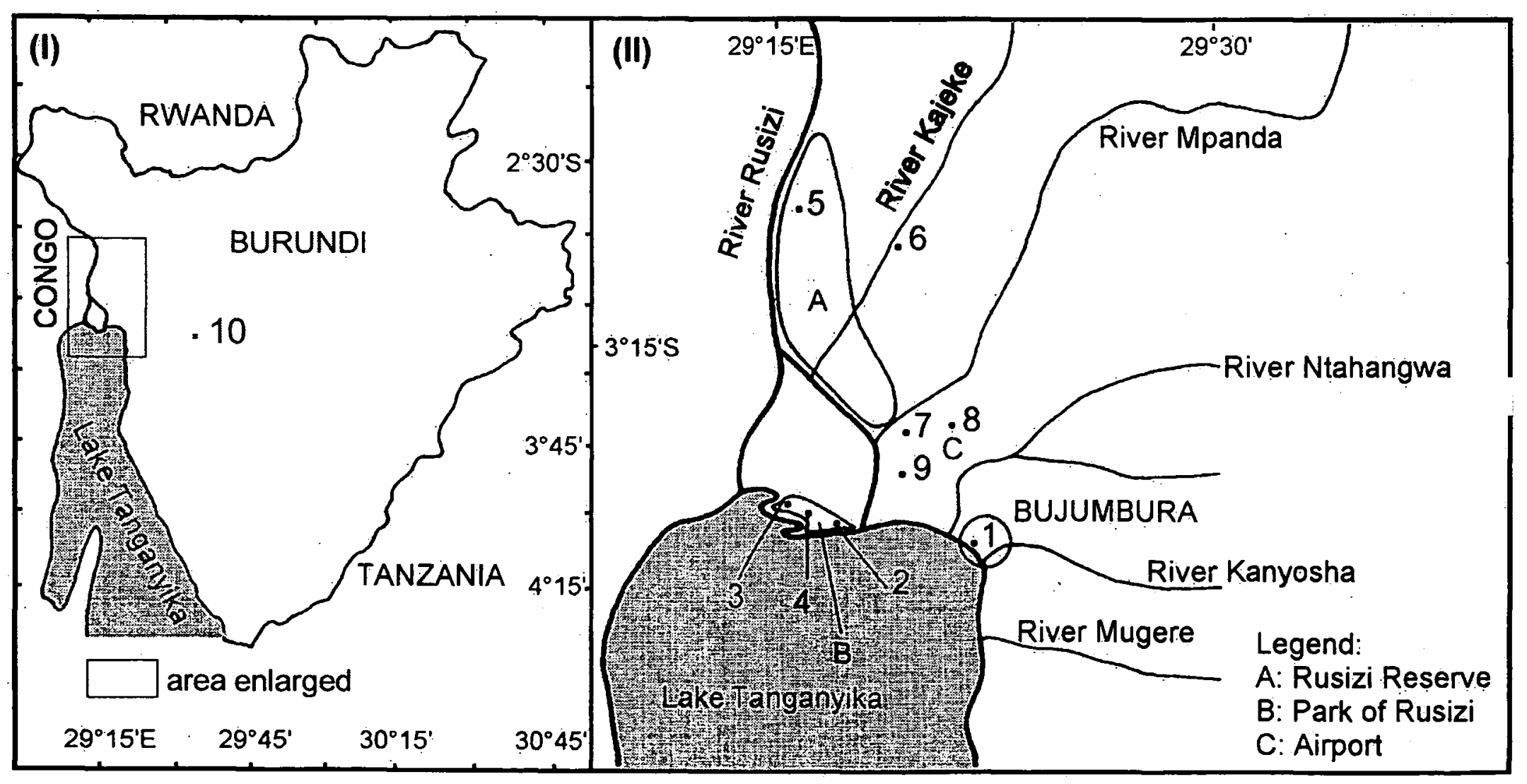

Map 1. Sampled localities in Burundi ; (I) Burundi, (II) River Rusizi floodplain.

Carte 1. Sites de récoltes au Burundi ; (I) Burundi, (II) Réseau de la plaine de la Rusizi. 
- Locality 9 : Abandoned fishpond in Rukaramu project (One sample, 26 March 1996).

A tenth locality is a water body in the Kashiru area near Ijenda, at approximately $40 \mathrm{~km}$ East- South East of Bujumbura, at an altitude of $1,700 \mathrm{~m}$. The climate of this region is relatively cold, with an average year temperature of $18^{\circ} \mathrm{C}$, and a short dry season (June - September) (two samples, 03 and 05 December 1989, leg. H.J. Dumont).

\section{Results and discussion}

A total of thirty-four Lecane were identified (Table 1). Only nine of these had already been recorded from the country before (Gillard 1957), while another five were known from Lake Tanganyika (Coulter in De Ridder 1991). These, together with a single endemic species described recently (Segers \& Baribwegure 1996), bring the total Lecane record of the country to thirty-five species. A record of only 35 Lecane from a region with diverse aquatic habitats in the tropics remains relatively poor, considering that other authors report more diverse taxocoenosis : De Ridder (1981) and Segers et al. (1993) list 43 and 59 Lecane, respectively. On the other hand, De Smet (1989), working on a similarly small sample collection recorded only 18 Lecane species. Obviously, differences in sampling intensity obscure any possible relevance regarding biodiversity of the observed differences in species numbers recorded.

Some of the taxa encountered are particularly noteworthy :

- Lecane aeganea Harring, 1914 (Figs 6-7). Although a known tropicopolitan species (Segers 1996), the present record is the first from Africa.

- Lecane baimaii Sanoamuang \& Savatenalinton, 1999 (Fig. 5). This species has only recently been described from four localities in Northeast Thailand (Sanoamuang \& Savatenalinton 1999). However, Segers et al. (1993) previously recorded the animal (as Lecane sp.) from the River Niger delta in Nigeria. Our records further illustrate the range of this Paleotropical species (Segers, in press.). The animal can be mistaken for L. aeganea (Figs 6-7), but is readily distinguished by its larger size, more strongly ornamented lori$\mathrm{ca}$, different foot pseudosegments shape and longer claws.

- Lecane decipiens (Murray, 1913) (Fig. 8). African records of this rare pantropical species are from Algeria (Segers 1995b), Ethiopia (Bryce 1931), Nigeria (Segers et al., 1993) Senegal (Berzins, 1959) and Uganda (Green 1967), although non-illustrated re- cords of this species should be interpreted with caution due to the confusion with L. hamata (Stokes) (Fig. 12).

- Lecane eswari Dhanapathi, 1976 (Figs 9-10). So far, this species was known from India and Thailand (Sanoamuang \& Segers 1997) only, and was listed as an Oriental endemic (Segers 1996). The present record of this species, which is distinguished from L. hastata (Murray, 1913) (Fig. 11) by its conical claws, extends its range to Africa, and reveals it to have a Paleotropical range.

- Lecane paxiana Hauer, 1940 (Fig. 20). The known distribution of this species is peculiar, as it has been recorded from Europe and Africa (Czechia, Germany and Nigeria : Segers 1995; Egypt : Klimowicz 1962). It is Eastern Hemisphere and, considering that the German records are from thermal springs, a warm-water species.

- Lecane subulata (Harring \& Myers, 1926) (Fig. 27). Segers (1996) regarded this species to be an arctic-temperate taxon, on account of its presence in habitats on high latitudes in both the Northern and Southern Hemisphere. The record of $L$. subulata in Burun$\mathrm{di}$, near the equator, is not so surprising taking into account that the animal occurred in a habitat at an altitude of about $1,700 \mathrm{~m}$ a.s.1. Because of the altitude, the region is the coolest of Burundi, with average temperatures of only $18^{\circ} \mathrm{C}$. De Smet \& Bafort (1991) reported on a similar record of a cold-water Lecane, L. perpusilla (Hauer, 1929) from a locality on Mount Kilimanjaro, but there are more documented cases of coldwater Rotifera occurring on high altitudes in the tropics (Segers 1996). De Ridder $(1987,1989)$ interprets the presence of cold-water Rotifera in African waters as glacial relicts. The present record of $L$. subulata is the first of this species from the African continent.

- Lecane sympoda Hauer, 1929 (Fig. 15). The distribution of $L$. sympoda was considered insufficiently known due to confusion with $L$. inopinata Harring \& Myers, 1926 (Fig. 14 ; Segers 1996). As new and reliable data are accumulating, it is now becoming clear that the species is, in fact, a warm-water Eastern Hemisphere taxon.

Of the 35 Lecane in the Burundian fauna, the majority are cosmopolitan taxa (14 spp., $40 \%$ ) or widely distributed species with thermophilic character (tropicopolitan : 12 spp., $34 \%$ ). A sizeable fraction of the fauna is restricted to the Eastern Hemisphere (6 spp., $17 \%$ ), either as strict paleotropical taxa or as widely distributed warm-water Eastern Hemisphere taxa. $L$. lateralis Sharma, 1978 and L. unguitata (Fadeev, 1925) are particularly interesting in this respect, as the- 
Table 1. Lecanidae recorded from Burundi.

Tableau 1. Lecanidae récoltés au Burundi.

*†Lecane aculeata (Jakubski, 1912)(Fig. 1): Loc. 1, 2, 3, 4, 6 (t)

**Lecane aeganea Harring, 1914 (Figs 6-7): Loc. 2 (t)

*Lecane arcula Harring, 1914 (Fig. 2): Loc. 3, 10 (t)

${ }^{*}$ Lecane baimaii Sanoamuang \& Savatenalinton, 1999 (Figs 3, 4): Loc. 7 (pal)

Lecane bulla (Gosse, 1851): Loc. 2, 3, 4, 5, 6, 7, 8, 9, 10 (c)

Lecane closterocerca (Schmarda, 1859): Loc. 2, 3, 4, 5, 7 (c)

${ }^{*}$ Lecane curvicornis (Murray, 1913)(Fig. 5): Loc. 2, 3, 4, 5, 6, 7, 8, $9(\mathrm{t})\left(\dagger^{(1)}\right.$ f. lofuana Myers, 1942)

*Lecane decipiens (Murray, 1913)(Fig. 8): Loc. 8, 9 (pan)

**Lecane eswari Dhanapathi, 1976 (Figs 9-10): Loc. 1, 8 (pal)

*Lecane furcata (Murray, 1913)(Fig. 13): Loc. 2, 3, 5, 6, 8, 9, 10 (c)

*Lecane haliclysta Harring \& Myers, 1926 (Fig. 17): Loc. 1 (t)

Lecane hamata (Stokes, 1896)(Fig. 12): Loc. 2, 3, 4, 5, 7, 8, 9 (c)

${ }^{*}$ Lecane hastata (Murray, 1913)(Fig. 11): Loc. 8, 9 (t)

*Lecane inermis (Bryce, 1892)(Fig. 19): Loc. 4, 5, 6, 7, 8 (c)

${ }^{*}$ Lecane inopinata Harring \& Myers, 1926 (Fig. 14): Loc. 3, 4, 7 (t)

*Lecane lateralis Sharma, 1978 (Fig. 22): Loc. 2, 4, 9 (pal)

Lecane leontina (Turner, 1892): Loc. 1, 9, 10 (t)

Lecane ludwigii (Eckstein, 1883)(Fig. 24) incl. f. *ercodes Harring, 1914 (Fig. 23): Loc. 9 (c)

Lecane luna (Mueller, 1776): Loc. 2, 3, 4, 6, 7, 8, 9 (c)

*†Lecane lunaris (Ehrenberg, 1832)(Fig. 25): Loc. 9 (c)

*†Lecane nana (Murray, 1913)(Fig. 18): Loc. 3, 4, 8 (c)

*Lecane obtusa (Murray, 1913)(Fig. 26): Loc. 3, 4 (t)

*Lecane papuana (Murray, 1913)(Fig. 30): Loc. 2, 3, 4, 6, 7, 9 (t)

*Lecane paxiana Hauer, 1940 (Fig. 20): Loc. 3, 4, 9 (w-e)

*Lecane pyriformis (Daday, 1905) (Fig. 21): Loc. 3, 4, 7 (c)

Lecane quadridentata (Ehrenberg, 1832): Loc. 2, 3, 4, 5, 7, 8, 9 (c)

${ }^{(2)}$ Lecane signifera (Jennings, 1896): Loc. $1(\mathrm{t})$

*Lecane stenroosi (Meissner, 1908)(Fig. 29): Loc. 1 (c)

**Lecane subulata (Harrings \& Myers, 1926)(Fig. 27): Loc. 10 (a-t)

*Lecane sympoda Hauer, 1929 (Fig. 15): Loc. 5 (w-e)

${ }^{(1)}$ Lecane tanganyikae Segers \& Baribwegure, 1996 (e)

*Lecane tenuiseta Harring, 1914 (Fig. 28): Loc. 4, 6 (c)

* Lecane undulata Hauer, 1938 (Fig. 16): Loc. 2, 3, 4 (t)

*Lecane unguitata (Fadeev, 1925)(Fig. 31): Loc. 5, 7, 8 (pal)

Lecane ungulata (Gosse, 1887): Loc. 5, 9 (c)

*: new to the Burundian fauna; ${ }^{* *}$ : new to Africa

$\dagger$ : Recorded from Lake Tanganyika by Gillard (1957) and/or Coulter in De Ridder (1991);

Record of $L$. vandenbrandei Gillard by Coulter in De Ridder (1991) is not included here.

${ }^{(1)}$ Not found in the present study.

${ }^{(2)}$ Recorded as L. ploenensis Voigt, 1902 by Gillard (1957)

(a-t): arctic-temperate; (c): cosmopolitan; (e): endemic; (pal): paleotropical; (pan): pantropical; $(\mathrm{t})$ : tropicopolitan; $(\mathrm{w}-\mathrm{e})$ : warm stenothermic Eastern Hemisphere. 

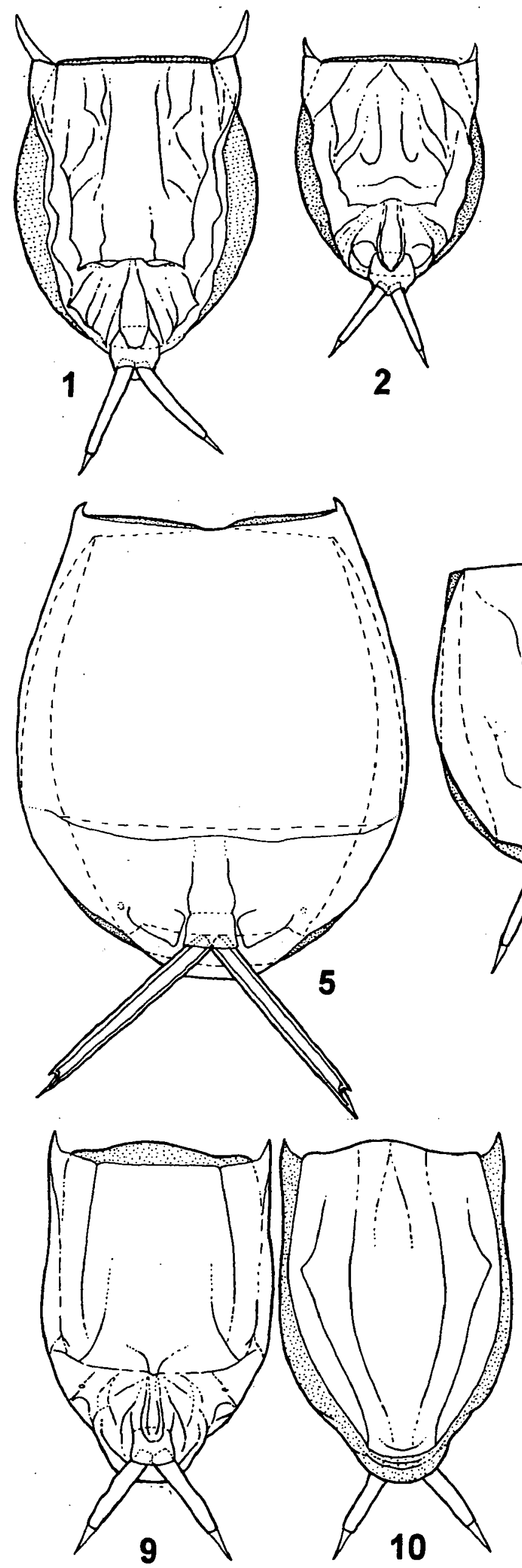

50pm

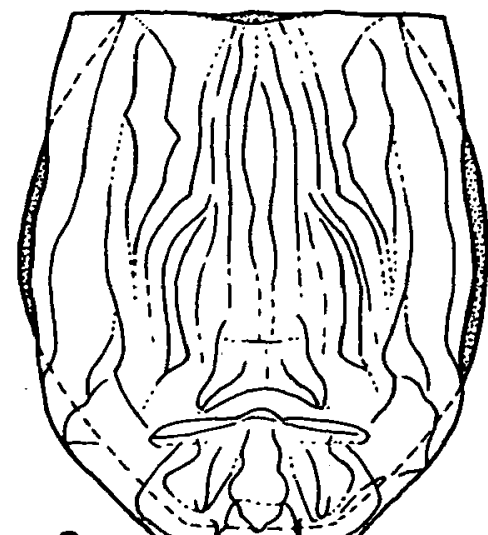

3
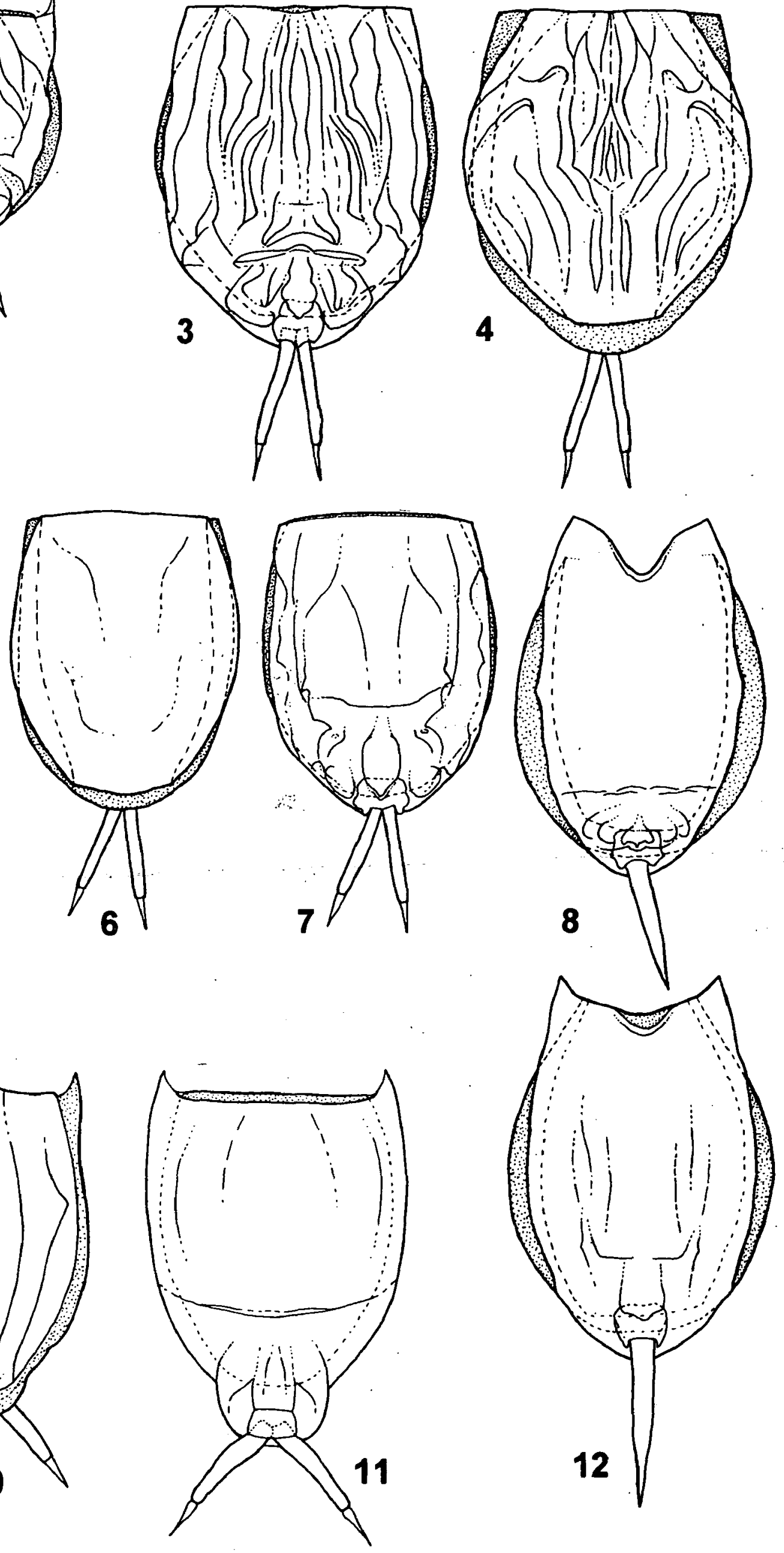

Figs 1-12. Lecane spp. $1:$ L. aculeata, $2: L$. arcula, 3-4 $:$ L. baimaii, $5:$ L. curvicomis, 6-7:L. aeganea, $8: L$ decipiens, 9-10: L. eswari, $11:$ L. hastata, $12:$ L. hamata. 

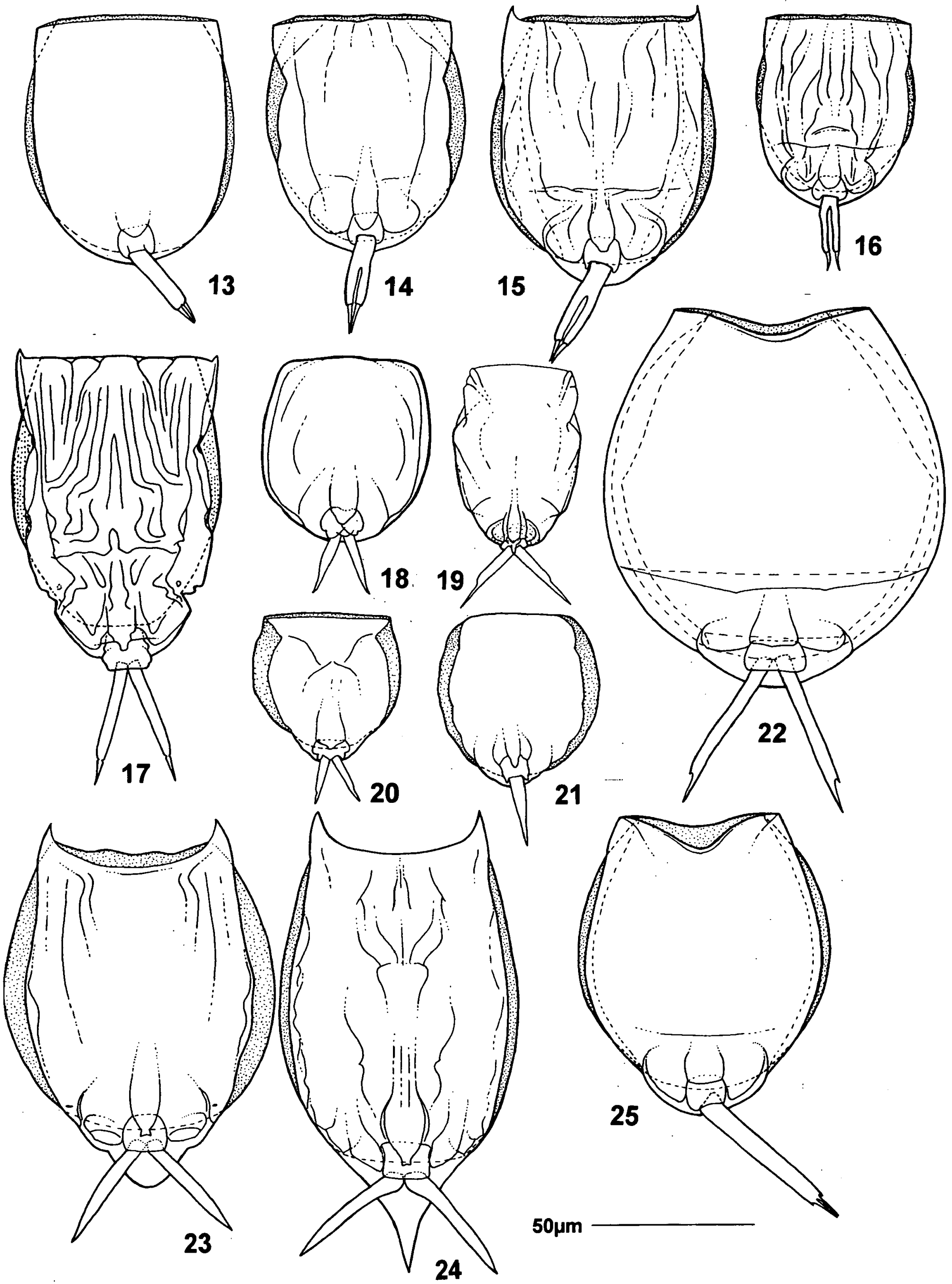

Figs 13-25. Lecane spp. $13:$ L. furcata, $14:$ L. inopinata, $15:$ L. sympoda, $16:$ L. undulata, $17:$ L. haliclysta, $18:$ L. nana, $19:$ L. inermis, $20:$ L. paxiana, $21:$ L. pyriformis, $22:$ L. lateralis, $23:$ L. ludwigii f. ercodes, $24:$ L. ludwigii f. typ., $25:$ L. lunaris. 


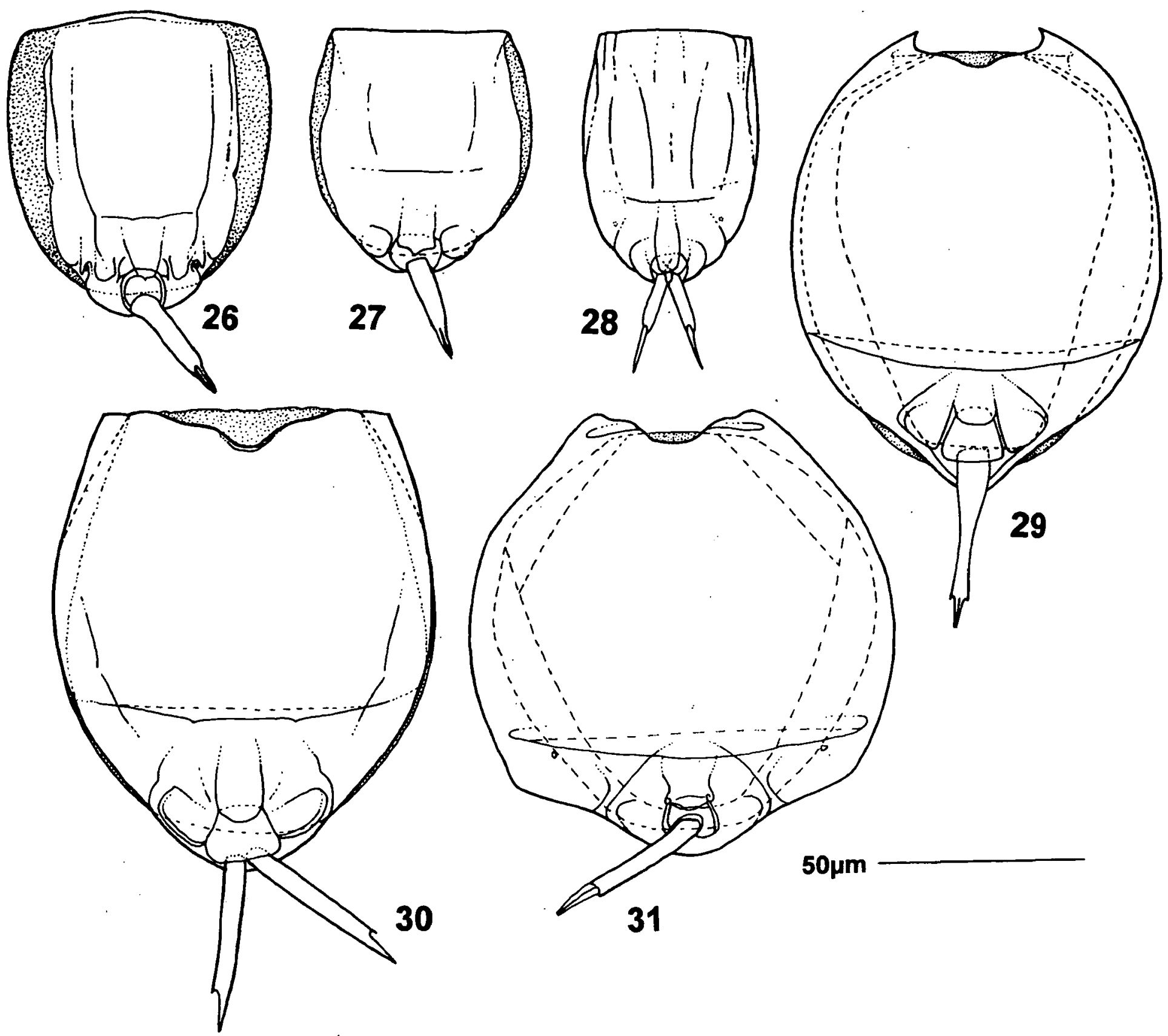

Figs 26-31. Lecane spp. $26:$ L. obtusa, $27:$ L. subulata, $28:$ L. tenuiseta, $29:$ L. stenroosi, $30:$ L. papuana, $31:$ L. unguitata.

se paleotropical species are both rather common. There is one each of Pantropical, endemic and, more noticeably, arctic-temperate taxa. On a total African Lecane fauna of some 70 species (Segers 1996 and present records), $10(14 \%)$ are Eastern Hemisphere, five (7\%) are Pantropical, seven (10\%) are endemic, and two (3\%) are arctic-temperate. Compared to this, the $\mathrm{Bu}$ rundian fauna lacks Pantropical and, especially, endemic taxa which is probably an artefact of limited sampling, as restrictedly distributed animals are mostly rare. Earlier results on Lepadellidae are similar (Baribwegure \& Segers, in press), showing a predominance of cosmopolitan and tropicopolitan taxa, and some Eastern Hemisphere and endemic taxa. No arctic-temperate Lepadellidae were recorded in that study.

\section{Acknowledgements}

The first author acknowledges a grant by the Belgian Administration for Development and Cooperation (B.A.D.C) to work on a Ph.D. dissertation. Samples from the littoral area of the Lake Tanganyika, from Kajeke and Rukoko were collected by Prof. H.J. Dumont and the late Dr. A. Caljon. Sampling in Rusizi Natural Park was aided by logistic support from CRRHA (Centre Régional de Recherche en Hydrobiologie Appliquée).

\section{References}

Baribwegure D. \& Segers H. in press. - Rotifera from Burundi : The Lepadellidae (Rotifera : Monogononta). Hydrobiologia. Berzins B. 1959. - Rotatorien aus Französisch-Westafrika. Bull. Inst. franç. Afrique Noire, A21 : 921-933.

Bryce D. 1931. - Report on the Rotifera. Mr. Omer Cooper's investigation of the Abessynian Freshwaters. Proc. Zool. Soc. Lond., 1931 : 865-878. 
De Ridder M. 1981. - Rotifera. in : Hydrobiological survey of the lake Bangweulu, Luapula river basin (Ed. J.J. Symoens), K.M.M.A., Tervuren, Belgium : 191 p.

De Ridder M. 1986. - Annoted checklist of non-marine rotifers. Rotifera from African inland waters. Zoologische Dokumentatie 2. K.M.M.A. Tervuren, Belgium : 123 p.

De Ridder M. 1987. - Distribution of rotifers in African fresh and inland saline waters. Hydrobiologia, $147: 9-14$.

De Ridder M. 1989. - Rotifers from Western Sudan. Hydrobiologia, 179 : 205-209.

De Ridder M. 1991. - Additions to the "Annoted Checklist of nonmarine Rotifers from African inland waters". Rev. Hydrobiol. Trop., 24 : 25-46.

De Ridder M. 1994. - Additions II to the "Annoted Checklist of non-marine Rotifers from African Inland waters". Biol. Jb. Dodonaea, $61: 99-153$.

De Smet W. H. 1989. - Contribution to the rotifer fauna of the Bas Zaire. 1. The rotifers from some small ponds and a river. Biol. $\mathrm{Jb}$. Dodonaea, $56: 115-131$.

De Smet W.H. \& Bafort J.M. 1990. - Rotifers from the Kilimanjaro. Biol. Jb. Dodonaea, 58 : 120-130.

Dussart H.H., Fernando C.H., Matsumura-Tundisi T. \& Shiel R.J. 1984. - A review of systematics, distribution and ecology of tropical freshwater zooplankton. Hydrobiologia, 113 : 77-91.

Gillard A. 1957. - Exploration hydrobiologique du Lac Tanganyika. Rotifères. (1946-1947). K.B.I.N., Brussels, Belgium : 26 p., 4 plates.

Green J. 1967. - Associations of Rotifera in the zooplankton of lake sources of the White Nile. J. Zool., Lond., 15 : 343-378
Klimowicz H. 1962. - Rotifers of small water bodies of Caïro botanical gardens. Pol. Arch. Hydrobiol., $10: 241-270$.

Sanoamuang L. \& Segers H. 1997. - Additions to the Lecane fauna (Rotifera : Monogononta) of Thailand. Int. Revue. ges. Hydrobiol., 82 : 545-530.

Sanoamuang L. \& Savatenalinton S. 1999. - New records of rotifers from Nakhon Ratschasima province, Northeast Thailand, with a description of Lecane baimaii n. sp. Hydrobiologia, 412 : 95-101.

Segers H. 1995a. - Rotifera 2. The Lecanidae (Monogononta). In : Guides to the Identification of the Microinvertebrates of the Continental Waters of the World 6. H.J. Dumont \& T. Nogrady (eds). SPB Academic Publishing BV., The Hague, The Netherlands : $226 \mathrm{p}$.

Segers H. 1995b. - World records of Lecanidae (Rotifera, Monogononta). Studiedocumenten K.B.I.N. 61, Brussels, Belgium : $114 \mathrm{p}$.

Segers H. 1996. - The Biogeography of littoral Lecane Rotifera. Hydrobiologia, 32 : 169-197.

Segers H. in press. - Zoogeography of the Southeast Asian Rotifera. Hydrobiologia.

Segers H. \& Baribwegure D. 1996. — On Lecane tanganyikae new species (Rotifera : Monogononta, Lecanidae). Hydrobiologia, 324 : $179-182$.

Segers H., Nwadiaro C.S. \& Dumont H.J. 1993. - Rotifera of some lakes in the floodplain of the river Niger (Imo State : Nigeria). II. Faunal composition and diversity. Hydrobiologia, 250 : 63-71. 